\title{
PERANAN KELUARGA TERHADAP PERKEMBANGAN KECERDASAAN EMOSIONAL ANAK
}

\author{
Oleh: Burhanuddin*
}

\begin{abstract}
Abstrak
Saat ini, banyak orang tua yang cukup puas dan senang ketika anak- anaknya mendapat nilai akademik yang bagus, tetapi tak cukup peduli terhadap sikap dan tingkah laku anak di luar rumah. Berdasarkan hasil survey di AS tentang IQ, ternyata ditemukan sebuah paradoks yang membahayakan. Skor IQ anak-anak makin tinggi, kecerdasan emosi mereka justru menurun. Disinilah pentingnya peranan keluarga di dalam melatih dan mengembangkan aspek emosional anak yang akan berpengaruh terhadap sikap dan tingkah laku anak di dalam maupun di luar rumah. Berdasarkan hal tersebut, maka dapat dirumuskan permasalahan pokok, yaitu : Bagaimana peranan keluarga terhadap perkembangan emosional anak ? Hasil penelitian menunjukkan bahwa keluarga mempunyai peranan penting dalam mengembangkan kecerdasan emosional anak, karena keluarga merupakan wahana untuk mendidik, mengasuh dan mensosialisasikan anak. Peran lingkungan keluarga di dalam mengembangkan dan mendidik aspek emosional anak diantaranya: Menciptakan suasana yang baik dalam lingkungan keluarga, setiap anggota keluarga melaksanakan hak dan kewajibannya masing-masing, menghindari segala sesuatu yang dapat merusak pertumbuhan jiwa anak, misalnya saling mengejek sesama anggota keluarga dan memberi kesempatan kepada anak untuk bergaul dengan teman-temannya di luar lingkungan keluarga.
\end{abstract}

Kata Kunci: Pendidikan, Keluarga, Perkembangan, EQ, Peranan

\section{PENDAHULUAN}

eluarga merupakan kesatuan hidup bersama yang pertama dikenal oleh anak. Oleh karena itu keluarga disebut sebagai "Primary Community", yaitu sebagai lingkungan pendidikan yang pertama dan

\footnotetext{
* Dosen UIN Alauddin Makassar DPK STAI Muhammadiyah Sinjai
} 
utama.

Keluarga disebut sebagai lingkungan pertama karena dalam keluarga inilah anak pertama kalinya mendapatkan pendidikan dan bimbingan. Dan keluarga disebut sebagai lingkungan pendidikan yang utama karena sebagian besar hidup anak berada dalam keluarga, maka pendidikan yang paling banyak diterima oleh anak ialah di dalam keluarga.

Tetapi banyak orang tua yang tidak menyadari hal ini. Para orang tua menyerahkan pendidikan anak sepenuhnya kepada sekolah atau pesantren. Mereka menganggap lembaga-lembaga itu seperti bengkel ketok magic yang dapat menyulap anak bengal menjadi insan shaleh dalam hitungan jam. Orang tua banyak yang beranggapan bahwa anak penyejuk mata dan jiwa itu seperti fast food yang dapat dipesan antar, yang penting orang tua punya uang untuk itu. Sebagian orang tua lupa, bahwa anak penyejuk mata dan jiwa itu adalah hasil dari sebuah proses pembentukan yang berkesinambungan. Jika di sekolah anak- anak diajari nilai-nilai Islam, maka setiba di rumah seringkali nilai-nilai itu dilunturkan oleh kenyataan bahwa orang tuannya sendiri tidak shalat dan tidak menunjukkan nilai-nilai Islam. Orang tua zaman sekarang yang pada umumnya pasangan suami-istri yang berkarier atau bekerja dari pagi hingga malam, beranggapan bahwa untuk mengembangkan pribadi anak dengan mendidik dan mengajar serta memperbaiki dan memperhalus tingkah laku anak didik ialah tugas utama guru atau ustadz di sekolah maupun pesantren.

Hal itu tidaklah salah, tetapi perlu diluruskan. Sebelum menyerahkan pendidikan sepenuhnya kepada sekolah, orang tua harus "membentuk karakter" anak di dalam keluarga. Orang tua harus menanamkan nilai-nilai agama, perilaku terpuji, kedisiplinan dan bagaimana bersikap terhadap orang yang lebih tua atau guru dan teman sebaya. Di samping memberikan pengajaran, yang paling terpenting ialah memberikan keteladanan. Percuma kalau anak diajarkan akhlak terpuji tetapi orang tuanya berakhlak buruk, tak akan berpengaruh jika anak diajarkan setiap pagi harus bangun pukul setengah lima tetapi orang tuanya tidak pernah sholat shubuh bahkan kesiangan. Teladan ini melahirkan gejala identifikasi positif, yakni penyamaan diri dengan orang yang ditiru dan hal ini penting sekali dalam rangka pembentukan kepribadian. ${ }^{3}$ Pengaruh orang tua sangat penting bagi anak. Pengkhianatannya atas amanat akan menjadi kejahatan yang panjang. Seorang anak datang ke dunia dengan hati yang bersih dan fitrahnya selalu menghadap kepada agama yang benar. Kemudian orang tuanya melakukan tindak pengrusakan terhadap fitrahnya dengan mencabut benih-benih iman dari hatinya dan menanamkan

${ }^{1}$ Alisuf Subri, Ilmu Pendidikan, (CV Pedoman Ilmu Jaya : Jakarta,1999), hal. 15

2 Muhammad Rasyid Dimas, 25 Cara Mempengaruhi Jiwa\&Akal Anak, (Pustaka Al-Kautsar:Jakarta,2006),hal. 10

3 Hasbullah, Dasar-Dasar Ilmu Pendidikan, (PT Raja Grafindo Persada : Jakarta,2006),hal. 4 


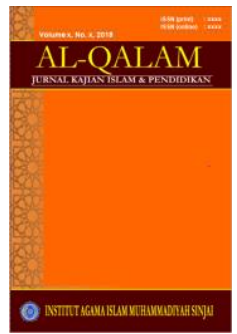

AL-QALAM

Jurnal Kajian Islam \& Pendidikan

Volume 07 No 022015

ISSN (print) : $1858-4152$

ISSN (online) : 2715-5684

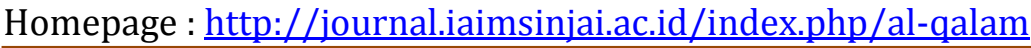

penyakit dan kedengkian di dalam jiwanya. ${ }^{4}$

Imam Ibnul Qayim berkata, "Berapa banyak orang yang mencelakakan anaknya di dunia dan akhirat dengan menyia-nyiakan pendidikannya dan membantunya mengikuti syahwat. Namun demikian, mereka tetap berpikir bahwa dirinya telah memuliakan anaknya. Padahal dia telah merendahkannya. Mereka berpikir bahwa dirinya telah menyayanginya. Padahal mereka telah berbuat zalim kepadanya. Oleh karena itu, mereka tidak akan mendapatkan manfaat dari anaknya, baik di dunia maupun di akhirat. Jika engkau menemukan kerusakan pada anak-anak, maka sebagian besar penyebabnya adalah orang tua." ${ }^{5}$

Salah satu fungsi keluarga ialah fungsi sosialisasi, yaitu fungsi keluarga dalam membentuk kepribadian anak. Melalui interaksi sosial dalam keluarga, anak mempelajari pola-pola tingkah laku, sikap, keyakinan, cita-cita dan nilai- nilai dalam masyarakat dalam rangka perkembangan kepribadiannya. ${ }^{6}$

Tapi saat ini, banyak orang tua yang cukup puas dan senang ketika anakanaknya mendapat nilai akademik yang bagus, tetapi tak cukup peduli terhadap sikap dan tingkah laku anak di luar rumah. Apakah anak sudah mengaplikasikan nilai-nilai kejujuran, konsisten, memiliki komitmen, dapat menjalin hubungan sosial dengan orang lain, berintegritas tinggi, berpikiran terbuka, memiliki kepercayaan diri, adil, empati, sabar, bijaksana, rasa semangat dan lain sebagainya? Berdasarkan hasil survey di AS tentang IQ, ternyata ditemukan sebuah paradoks yang membahayakan. Skor IQ anak-anak makin tinggi, kecerdasan emosi mereka justru menurun. ${ }^{7}$ Hal ini juga terjadi di Indonesia, banyak anak-anak pintar dan cerdas tapi mereka lebih mudah depresi, lebih cepat putus asa dan mudah marah. Jika kita perhatikan fenomena kehidupan rumah tangga sekarang ini, kita akan menemukan bahwa banyak kedua orang tua sangat perhatian terhadap kesehatan fisik anak-anak mereka. Jika salah satu anak mereka terserang penyakit, mereka akan sibuk dan bergegas untuk mengobatinya. Akan tetapi jika salah satu anak-anak mereka terserang penyakit dalam akhlak dan perilakunya, mereka tidak terlalu mempedulikannya dan tidak merasa sebagai suatu kesalahan. Kemudian keduanya sibuk dengan urusan masing-masing. Mereka tidak peduli dan tidak menyadari musibah itu. Disinilah pentingnya peranan keluarga di dalam melatih dan mengembangkan aspek emosional anak yang akan berpengaruh terhadap sikap dan tingkah laku anak

\footnotetext{
${ }^{4}$ Anas Ahmad Karzun, Anak Adalah Amanat, (Qisthi Press :Jakarta, 2006), hal. 3

${ }^{5}$ Ibid, hal. 4

${ }^{6}$ Alisuf Subri, Ilmu Pendidikan, (CV Pedoman Ilmu Jaya : Jakarta,1999), hal 15

7 Daniel Goleman, Working With Emotional Intelligence, (New York : Bantam Books, 1999), hal.13
} 
di dalam maupun di luar rumah. Keluarga, yang di dalamnya termasuk orang tua dan saudara-saudara yang tinggal satu rumah, harus menciptakan suasana yang kondusif, edukatif dan menyenangkan agar anak-anak memiliki mental yang sehat dan emosi yang stabil.

Berdasarkan uraian di atas, dapat kita ketahui bahwa betapa pentingnya kontribusi keluarga agar proses perkembangan aspek emosional anak berjalan sesuai dengan yang kita harapkan. Berdasarkan kenyataan yang ada, maka alasan saya membahas peran keluarga disebabkan timbulnya beberapa masalah, antara lain : a) Tidak adanya kontribusi dari keluarga berpengaruh terhadap perkembangan kecerdasan emosional anak; b) Kurangnya kesadaran orang tua bahwa keluarga sebagai lingkungan pendidikan yang utama dan pertama; c) Mayoritas orang tua lebih menekankan IQ daripada EQ; d) Sebagian orang tua belum memberikan keteladanan yang baik sebagai modal utama pembentukan kepribadian anak; e) Orang tua kurang memperhatikan sikap dan perilaku anak; dan f) Aspek emosional anak sangat dipengaruhi oleh keadaan dan kondisi keluarga.

Agar penulisan makalah ini mempunyai arah dan tujuan yang jelas, maka penulis membatasi masalah pada peran keluarga terhadap perkembangan kecerdasan emosional anak dengan mencermati dua hal, yaitu: a) Peranan keluarga ialah tindakan, kewajiban orang tua terhadap anaknya baik dalam mendidik, membimbing, melindungi dan menghidupi dengan cara-cara yang tepat dan kondisi keluarga tempat si anak tinggal; dan b) Kecerdasan emosional ialah kemampuan anak untuk memahami perasaan dan emosi diri sendiri maupun orang lain, sehingga bisa berinteraksi dengan baik. Kecerdasan emosi juga melahirkan sifat dan sikap positif seperti percaya diri, jujur, rendah hati, sabar, empati, bijaksana dan lain sebagainya.

Berdasarkan latar belakang yang dikemukakan di atas, maka dapat dirumuskan permasalahan pokok, yaitu : "Bagaimana peranan keluarga terhadap perkembangan emosional anak ?"

Penelitian dalam tulisan bertujuan untuk: a) Untuk mengetahui peranan keluarga terhadap perkembangan kecerdasan emosional anak.; b) Untuk mengetahui upaya-upaya dari keluarga dan orang tua dalam mengoptimalkan perkembangan emosi anak.

Manfaat dari penelitian ini antara lain: a) Penelitian ini diharapkan dapat menjadi bahan masukkan bagi keluarga dalam rangka mendidik anak.; b) Dapat memberikan kontribusi dalam rangka mengoptimalkan pelaksanaan pendidikan karakter di dalam keluarga.; c) Untuk memperluas paradigma berpikir dan khazanah keilmuan dalam bidang pendidikan Islam di dalam keluarg

\section{PEMBAHASAN}

\section{A. Fungsi dan Peranan Keluarga}

\section{Fungsi Keluarga}


Dalam kehidupan manusia, keperluan dan hak kewajiban, perasaan dan keinginan keluarga sangat mendukung pertumbuhan dan perkembangan diri seseorang dan akan binasalah pergaulan seseorang bila orang tua tidak menjalankan tugasnya sebagai pendidik. Secara sosiologi keluarga dituntut berperan dan berfungsi untuk menciptakan suatu masyarakat yang aman, tentram, bahagia dan sejahtera, yang kesemuanya itu harus dijalankan oleh keluarga sebagai lembaga social yang terkecil. Dalam buku keluarga muslim dalam masyarakat modern, dijelaskan bahwa: "Berdasarkan pendekatan budaya keluarga sekurang-kurangnya mempunyai tujuh fungsi, yaitu fungsi biologis, edukatif, religius, protektif, sosialisasi, rekreatif dan ekonomi."

a). Fungsi Biologis

Fungsi biologis keluarga berhubungan dengan "pemahamanpemahaman kebutuhan biologis anggota keluarga". ${ }^{9}$ Di antara kebutuhan biologis ini kebutuhan akan keterlindungan fisik guna melangsungkan kehidupannya, keterlindungan kesehatan, keterlindungan dari rasa lapar, haus, kedinginan, kepanasan, kelelahan, kesegaran fisik. Termasuk juga kebutuhan biologis ialah kebutuhan mendapatkan keturunan dengan melahirkan anak-anak sebagai generasi penerus dan dengan kata lain kelanjutan identitas keluarga.

b). Fungsi Edukatif

Yang dimaksud fungsi edukatif ialah "fungsi keluarga yang berkaitan dengan pendidikan anak khusussnya serta pembinaan pendidikan anggota keluarga pada umumnya." ${ }^{10}$ Fungsi ini mengharuskan setiap orang tua mengkondisikan kehidupan keluarga menjadi situasi pendidikan yang dapat mendorong anakanak untuk melakukan perbuatan-perbuatan yang mengarah kepada tujuan pendidikan. Dalam melaksanakan fungsi edukatif ini keluarga sebagai salah satu tri pusat pendidikan, dalam hal ini orang tua memegang peranan utama dalam proses pembelajaran anaknya terutama dikala mereka belum dewasa. Kegiatan pembelajaran orang tua antara lain melalui asuhan, pembiasaan dan contoh teladan.

c). Fungsi Religius

${ }^{8}$ Jalaludin Rakhmat dan Mukhtar Gandaatmaja, Keluarga Muslim dalam Masyarakat Modern, (Bandung : Remaja Rosda Karya, 1994),cet.Ke-2, hal.20-21

${ }^{9}$ M.I. Soelaeman, Pendidikan dalam Keluarga, (Bandung : CV.Alpabeta,1994) hal.113

${ }^{10}$ Ibid., hal.685 
Fungsi ini berkaitan dengan kewajiban keluarga untuk memperkenalkan dan mengajak anak serta anggota keluarga lainnya dalam kehidupan beragama dengan melakukan semua kegiatan yang sesuai dengan ajaran-ajaran dan ketentuan agama dengan menuju keridhoan-Nya.

d). Fungsi Protektif

Fungsi protektif (perlindungan) dalam keluarga ini berfungsi "memelihara merawat dan melindungi si anak baik fisik maupun sosialnya." Fungsi ini menangkal pengaruh kehidupan pada saat sekarang dan masa yang akan datang.

e). Fungsi Sosialisasi

Fungsi sosialisasi berkaitan dengan mempersiapkan anak menjadi anggota masyarakat yang baik, dalam melaksanakan fungsi ini "keluarga membentuk kepribadian anak melalui intreraksi social, mempelajari pola-pola tingkah laku, sikap, keyakinan, cita-cita dan nilai-nilai dalam masyarakat yang kesemuanya itu dilakukan dalam rangka perkembangan kepribadiannya."

f). Fungsi Ekonomis

Fungsi ekonomis keluarga meliputi "pencarian nafkah, perencanaan serta pembelajaran dan manfaatnya." Pada dasarnya yang mengemban kesejahteraan keluarga, termasuk pencarian nafkah keluarga. Akan tetapi ini tidak berarti bahwa istri tidak diperkenankan mencari nafkah, namun dalam keadaan demikian tanggung jawab yang diemban oleh seorang suami tidaklah diserahkan istri sepenuhnya karena hal ini dilakukannya untuk masa depan anak-anak dan keluargannya.

g). Fungsi Rekreatif

Fungsi ini tidak harus dengan kemewahan serba ada, melainkan melalui penciptaan suasana kehidupan yang tenang dan damai. Fungsi rekreatif ini juga dapat membawa anggota keluarga dalam merealisasikan dirinya dalam suasana yang bebas dan nyaman sebagai selingan dari kesibukan sehari-hari. Hal ini dapat juga di dapat dengan mencari hiburan di alam segar bersama keluarga.

Dengan melihat fungsi keluarga di atas, hendaknya dalam pelaksanaan fungsi haruslah seiring sejalan antara yang satu dengan fungsi yang lain, ketujuh fungsi tersebut tidak dapat dipisahkan. Sebuah keluarga tanpa fungsi biologis, maka keluarga akan punah, tidak ada generasi penerus yang akan melanjutkan identitas keluarga. Tanpa fungsi edukatif generasi yang dilahirkan akan berantakan, tanpa fungsi religius generasi akan tersesat, tanpa fungsi protektif tidak ada ketentraman dan kedamaian dalam keluarga, tanpa fungsi sosialisasi akan muncul generasi-generasi yang 
memiliki sifat individual yang tinggi, tanpa fungsi rekreatif rumah tangga terasa membosankan dan meliputi kejenuhan dan tanpa fungsi ekonomis kesejahteraan rumah tangga akan goyah.

\section{Peranan Keluarga}

Setiap keluarga terdiri atas beberapa anggota keluarga yang masing- masing anggota keluarga memiliki peranannya sendiri-sendiri sesuai dengan kedudukannya dalam keluarga yang bersangkutan, sehingga menambah keharmonisan kehidupan keluarga. Dalam keluarga sosok seorang ibu sangat diperlukan sebagai pendidik dasar bagi anakanaknya, maka dari itu seorang ibu hendaklah seorang yang bijaksana dan pandai mendidik anak-anaknya. Sesuai dengan fungsi serta tanggung jawabnya sebagai anggota keluarga. Peran ibu dalam pendidikan anak- anaknya adalah : 1) Sumber dan pemberi kasih sayang; 2) Pengasuh dan pemelihara; 3) Tempat mencurahkan isi hati; 4) Pengatur kehidupan dalam rumah tangga; 5) Pembimbing hubungan pribadi; dan 6) Pendidik dalam segi emosional. ${ }^{11}$

Bukan saja peran seorang ibu yang sangat dibutuhkan dalam keluarga. Tetapi peran seorang ayah juga lebih sangat dibutuhkan dalam membentuk perkembangan keluarga. Adapun peranan ayah di antaranya : 1) Sumber kekuasaan dalam keluarga; 2) Penghubung intern keluarga dalam masyarakat/dunia luar; 3) Pemberi perasaan aman bagi seluruh anggota keluarga; 4) Pelindung terhadap ancaman dari luar; 5) Hakim yang mengadili jika terjadi perselisihan; 6) Pendidik dalam segi-segi rasional.

\section{Peranan Keluarga Bagi Pendidikan Anak}

Anak merupakan titipan (amanah) dari Allah SWT. Setiap anak yang dilahirkan dalam keadaan suci, sebagaiman sabda Rasulullah SAW :

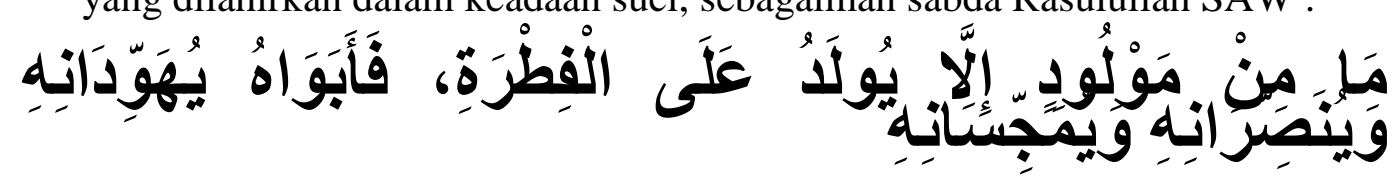

"Setiap anak dilahirkan itu dalam keadaan suci, maka orang tuanyalah yang menjadikan anak menjadi yahudi, nasrani dan majusi". (HR. Muslim). ${ }^{12}$

Hadits di atas menyatakan orang tua merupakan pemeran utama

\footnotetext{
${ }^{11}$ M.Ngalim Poerwanto, Ilmu Pendidikan (Teoritis dan Praktis), Bandung : PT.Remaja Rosdakarya, 1995), cet.Ke-8, hal.82

${ }^{12}$ Imam Muslim, Shahih Muslim, (Al-Musriyah: Al Maktabah Maktabuha, 1924), Juz 16
} 
dalam mendidik anak-anaknya. Secara kodrati bayi dilahirkan dalam keadaan suci, keluargalah yang membesarkannya menjadi baik atau buruk. Keluarga dan pendidikan dalam keluarga berpengaruh, bahkan dapat menghilangkan sifat-sifat khas yang diwarisinya. Yang dimaksud fitrah dalam hadits di atas ialah potensi yang dibawa oleh anak semenjak lahir. Orang tua dalam hal ini bertanggung jawab untuk selalu mengembangkan potensi tersebut agar lebih baik. Dalam konsep Islam, keluarga adalah penanggung jawab utama terpeliharanya potensi tersebut.

Para ahli pendidikan dan para ahli ilmu jiwa sepakat bahwa menanamkan pendidikan pada anak sejak dini (dalam rumah tangga) adalah masalah yang strategis. Kita ketahui bahwasannya pendidikan dalam keluarga merupakan pendidikan pertama dan utama. Disini anak didik sepanjang waktu dan meliputi berbagai bidang kehidupan, seperti kesehatan, kebersihan, sopan santun pergaulan, disiplin pribadi, tanggung jawab, kerja sama, pengenalan kehidupan keagamaan dan lain sebagainnya. Hal ini akan mempunyai pengaruh yang sangat mendalam bagi pembentukan kepribadian anak dan watak kepribadiannya di masa yang akan datang, karenanya, suatu rumah tangga yang di dalamnya penuh dengan liputan kasih sayang dan suasana keislaman, maka akan tumbuh menjadi pribadi-pribadi yang wajar.

Sedangkan dalam suatu rumah tangga yang di dalamnya telah terputus hubungan dan kasih sayang cinta, penuh dengan suasana muram, maka dari rumah tersebut akan tumbuh pribadi-pribadi yang tidak diinginkan. Mereka kelak akan menjadi beban bagi masyarakat dan orangorang yang berada dalam rumah itu sendiri.

Hubungan orang tua yang efektif penuh kemesraan dan tanggung jawab yang didasari oleh kasih sayang yang tulus, menyebabkan anakanaknya akan mampu mengembangkan aspek-aspek kegiatan manusia yang pada umumnya ialah kegiatan yang bersifat individual, kegiatan social dan keagamaan. ${ }^{13}$

Suasana keluarga yang baik sekurang-kurangnya harus ditunjang oleh tiga faktor antara lain : $:^{14}$

1. Keluarga dapat memberikan suasana emosional yang baik bagi anakanak, misalnya perasaan senang, aman, disayangi dan dilindungi. Suasana ini dapat tercipta apabila kehidupan rumah tangga diliputi suasana yang sama.

2. Mengetahui dasar-dasar kependidikan terutama yang berkaitan dengan kewajiban dan tanggung jawab orang tua terhadap

${ }^{13}$ Hasan Basri, Keluarga Sakinah, (Yogyakarta:Pustaka Pelajar 1995) cet. Ke -2, hal.90

14 Hery Noer Aly, MA, Ilmu Pendidikan Islam, (Jakarta: Logos, 1999) cet. Ke-2,hal.212-217 
perkembangan mental anak. Lebih lanjut, orang tua juga bertanggung jawab pada tujuan dan isi pendidikan yang diberikan kepada anaknya.

3. Bekerja sama dengan lembaga pendidikan dimana orang tua memberikan amanatnya dalam mendidik anaknya. Bentuk kerja sama ini antara lain menyangkut anak belajar dan mengerjakan pekerjaan rumah (PR) dari lembaga pendidikan tersebut.

\section{B. Keterkaitan Keluarga Dengan Karakter Anak}

\section{Keluarga sebagai Wahana Pertama dan Utama Pendidikan Karakter Anak}

Para sosiolog meyakini bahwa keluarga memiliki peran penting dalam menentukan kemajuan suatu bangsa, sehingga mereka berteori bahwa keluarga adalah unit yang penting sekali dalam masyarakat, sehingga jika keluarga-keluarga yang merupakan fondasi masyarakat lemah, maka masyarakat pun akan lemah. Oleh karena itu, para sosiolog meyakini bahwa berbagai masalah masyarakat - seperti kejahatan seksual dan kekerasan yang merajalela, serta segala macam kebobrokan di masyarakat - merupakan akibat dari lemahnya institusi keluarga. ${ }^{15}$ Orang tua adalah pembina pribadi yang pertama dalam hidup anak. Kepribadian orang tua, sikap dan gaya hidup mereka, merupakan unsur-unsur pendidikan yang tidak langsung, yang dengan sendirinya akan masuk ke dalam pribadi anak yang sedang bertumbuh itu. Sikap anak terhadap guru agama dan pendidikan agama di sekolah sangat dipengaruhi oleh sikap kedua orang tuanya terhadap agama dan guru agama khususnya. ${ }^{16}$ Bagi seorang anak, keluarga merupakan tempat pertama dan utama bagi pertumbuhan dan perkembangannya. Fungsi utama keluarga adalah "sebagai wahana untuk mendidik, mengasuh, dan mensosialisasikan anak, mengembangkan kemampuan seluruh anggotanya agar dapat menjalankan fungsinya di masyarakat dengan baik, serta memberikan kepuasan dan lingkungan yang sehat guna tercapainya keluarga, sejahtera".

\section{Aspek-aspek Penting dalam Pendidikan Karakter Anak}

Untuk membentuk karakter anak diperlukan syarat-syarat mendasar bagi terbentuknya kepribadian yang baik. Ada tiga kebutuhan dasar anak yang harus dipenuhi, yaitu maternal bonding, rasa aman, dan stimulasi fisik dan mental.

15 Melly Latifah, "Peranan Keluarga Dalam Pendidikan Karakter Anak", dari www.blogspot.com, 1 Maret 2008

${ }^{16}$ Zakiah Daradjat, Ilmu Jiwa Agama, (Jakarta: PT Bulan Bintang,2003), Cet.16, hal. 67 
a). Maternal bonding (kelekatan psikologis dengan ibunya) merupakan dasar penting dalam pembentukan karakter anak karena aspek ini berperan dalam pembentukan dasar kepercayaan kepada orang lain (trust) pada anak. Kelekatan ini membuat anak merasa diperhatikan dan menumbuhkan rasa aman sehingga menumbuhkan rasa percaya. Menurut Erikson, dasar kepercayaan yang ditumbuhkan melalui hubungan ibu-anak pada tahun-tahun pertama kehidupan anak akan memberi bekal bagi kesuksesan anak dalam kehidupan sosialnya ketika ia dewasa. Dengan kata lain, ikatan emosional yang erat antara ibu-anak di usia awal dapat membentuk kepribadian yang baik pada anak.

b). Kebutuhan akan rasa aman yaitu kebutuhan anak akan lingkungan yang stabil dan aman. Kebutuhan ini penting bagi pembentukan karakter anak karena lingkungan yang berubah-ubah akan membahayakan perkembangan emosi bayi. Pengasuh yang bergantiganti juga akan berpengaruh negatif pada perkembangan emosi anak.

c). Kebutuhan akan stimulasi fisik dan mental juga merupakan aspek penting dalam pembentukan karakter anak. Tentu saja hal ini membutuhkan perhatian yang besar dari orang tua dan reaksi timbal balik antara ibu dan anaknya. Menurut pakar pendidikan anak, seorang ibu yang sangat perhatian (yang diukur dari seringnya ibu melihat mata anaknya, mengelus, menggendong, dan berbicara kepada anaknya) terhadap anaknya yang berusia usia di bawah enam bulan akan mempengaruhi sikap bayinya sehingga menjadi anak yang gembira, antusias mengeksplorasi lingkungannya, dan menjadikannya anak yang kreatif.

\section{Pola Asuh Menentukan Keberhasilan Pendidikan Karakter Anak dalam Keluarga}

Keberhasilan keluarga dalam menanamkan nilai-nilai kebajikan (karakter) pada anak sangat tergantung pada jenis pola asuh yang diterapkan orang tua pada anaknya. Pola asuh dapat didefinisikan sebagai pola interaksi antara anak dengan orangtua yang meliputi pemenuhan kebutuhan fisik (seperti makan, minum dan lain- lain) dan kebutuhan psikologis (seperti rasa aman, kasih sayang dan lain-lain), serta sosialisasi norma-norma yang berlaku di masyarakat agar anak dapat hidup selaras dengan lingkungannya. Dengan kata lain, pola asuh juga meliputi pola interaksi orang tua dengan anak dalam rangka pendidikan karakter anak.

Secara umum, Tutu April A.Suseno mengkategorikan pola asuh menjadi tiga jenis, yaitu : Pola asuh otoriter, pola asuh permisif, dan pola 
asuh otoritatif. Pola asuh otoriter mempunyai ciri orangtua membuat semua keputusan, anak harus tunduk, patuh, dan tidak boleh bertanya. Orang tua otoriter memberlakukan peraturan-peraturan yang ketat dan menuntut agar peraturan-peraturan itu dipatuhi. Mereka yakin bahwa anak-anak harus "berada di tempat yang telah ditentukan" dan tidak boleh menyuarakan pendapatnya. Orang tua otoriter berusaha menjalankan rumah tangga yang didasarkan pada struktur dan tradisi, walaupun dalam banyak hal, tekanan mereka akan keteraturan dan pengawasan membebani anak. Dalam bukunya, Raising a Responsible Child, Elizabeth Elis menulis, "Banyak penelitian menyatakan bahwa anak-anak yang berasal dari keluarga yang menerapkan keotoriteran dan pengawasan ketat tidak memperlihatkan pola yang berhasil. Anak-anak cenderung tidak bahagia, penyendiri dan sulit memercayai orang lain. Kadar harga dirinya paling rendah (dibanding anak-anak yang dibesarkan oleh orang tua yang tidak terlalu mengatur". ${ }^{17}$

Ada beberapa kesalahan orang tua dalam mendidik anak yang dapat mempengaruhi perkembangan kecerdasan emosi anak sehingga berakibat pada pembentukan karakternya, yaitu:

a). Kurang menunjukkan ekspresi kasih sayang baik secara verbal maupun fisik.

b). Kurang meluangkan waktu yang cukup untuk anaknya.

c). Bersikap kasar secara verbal, misainya menyindir, mengecilkan anak, dan berkata- kata kasar.

d). Bersikap kasar secara fisik, misalnya memukul, mencubit, dan memberikan hukuman badan lainnya.

e). Terlalu memaksa anak untuk menguasai kemampuan kognitif secara dini.

f). Tidak menanamkan "good character' kepada anak.

\section{Pengaruh Lingkungan Keluarga Terhadap Pendidikan Anak-Anak}

Keadaan tiap-tiap keluarga berlain-lainan satu sama lain. Ada keluarga yang kaya, ada keluarga yang kurang mampu. Ada keluarga yang besar (banyak anggota keluarganya), dan ada pula keluarga kecil. Ada keluarga yang selalu diliputi oleh suasana tenang dan tentram, ada juga yang selalu gaduh, bercekcok dan lain sebagainya. Dengan sendirinya, keadaaan dalam keluarga yang bermacam-macam coraknya itu akan membawa pengaruh yang berbeda-beda pula terhadap pendidikan anak-anak.

${ }^{17}$ Tutu April A.Suseno, EQ Orang Tua VS EQ Anak, (Yogyakarta:Diglossia Printika, 
Dari kecil anak dipelihara dan dibesarkan oleh dan dalam keluarga. Segala sesuatu yang ada dalam keluarga, baik yang berupa benda-benda dan orang-orang serta peraturan-peraturan dan adat istiadat yang berlaku dalam keluarga itu sangat berpengaruh dan menentukan corak perkembangan anak-anak.

Bagaimana cara mendidik yang berlaku dalam keluarga itu, demikianlah cara anak itu mereaksi terhadap lingkungannya. Jika di dalam lingkungan keluarganya, misalnya anak itu sering ditertawakan dan diejek jika tidak berhasil melakukan sesuatu, maka dengan tidak sadar ia akan selalu berhati-hati tidak akan mencoba melakukan yang baru atau yang sukar. Ia akan menjadi orang yang selalu diliputi oleh keragu-raguan.

Jika di dalam lingkungan keluarganya ia selalu dianggap dan dikatakan bahwa ia masih kecil dank karena itu belum dapat melakukan sesuatu, kemungkinan besar anak itu akan menjadi orang yang selalu merasa kecil, tidak berdaya, tidak sanggup mengerjakan sesuatu. Ia akan berkembang menjadi orang yang bersifat masa bodoh, tidak atau kurang mempunyai perasaan harga diri.

Sebaliknya, jika anak itu dibesarkan dan dididik oleh orang tua atau lingkungan keluarga yang mengetahui akan kehendaknya dan berdasarkan kasih sayang kepadanya, ia akan tumbuh menjadi anak yang tenang dan mudah menyesuaikan diri terhadap orang tau dan anggota-anggota keluarga lainnya, serta terhadap teman-temannya. Wataknya akan berkembang dengan tidak mengalami kesulitan-kesulitan yang besar.

\section{PENUTUP}

Dari uraian di atas dapatlah penulis simpulkan bahwa, keluarga mempunyai peranan penting dalam mengembangkan kecerdasan emosional anak, karena keluarga merupakan wahana untuk mendidik, mengasuh dan mensosialisasikan anak. Peran lingkungan keluarga di dalam mengembangkan dan mendidik aspek emosional anak diantaranya: Menciptakan suasana yang baik dalam lingkungan keluarga, setiap anggota keluarga melaksanakan hak dan kewajibannya masing-masing, menghindari segala sesuatu yang dapat merusak pertumbuhan jiwa anak, misalnya saling mengejek sesama anggota keluarga dan memberi kesempatan kepada anak untuk bergaul dengan teman-temannya di luar lingkungan keluarga.

Oleh krena itu, kepada para orang tua, hendaklah memberikan keteladanan yang baik, mendidik dan mengajarkan pendidikan agama sejak dini dengan kasih sayang dan persahabatan. Seperti ungkapan yang telah penulis paparkan sebelumnya, "Jika anak dibesarkan dengan celaan, dia belajar memaki. Jika anak dibesarkan dengan permusuhan, ia belajar berkelahi. Jika anak dibesarkan dengan cemoohan, ia belajar rendah diri. Jika anak dibesarkan 


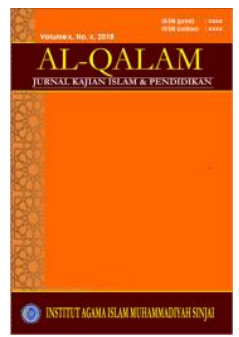

AL-QALAM

Jurnal Kajian Islam \& Pendidikan

Volume 07 No 022015

ISSN (print) : $1858-4152$

ISSN (online) : 2715-5684

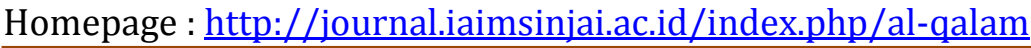

dengan penghinaan, ia belajar menyesali diri. Jika anak dibesarkan dengan toleransi, ia belajar menahan diri. Jika anak dibesarkan dengan dorongan, dia belajar percaya diri. Jika anak dibesarkan dengan pujian, ia belajar menghargai. Jika anak dibesarkan dengan sebaik-baiknya perlakuan, ia belajar keadilan. Jika anak dibesarkan dengan rasa aman, ia belajar menaruh kepercayaan. Jika anak dibesarkan dengan dukungan, ia belajar menyayangi diri. Jika anak dibesarkan dengan kasih sayang dan persahabatan, ia belajar menemukan cinta dalam kehidupan."

Kepada tokoh agama dan tokoh masyarakat hendaklah lebih dekat dengan kehidupan anak-anak dan ikut berpartisipasi pada kegiatan anakanak. Para tokoh agama hendaknya menyampaikan kisah-kisah moral islami, agar anak bisa mengerti tentang akhlak dan moral nabi, sahabat-sahabat nabi dan para ulama terdahulu yang sudah teruji akhlaknya, sehingga anak-anak bisa mencontoh sifat dan perilaku mereka.

Kepada guru dan para pendidik, hendaknya mencintai anak-anak muridnya, ilmu yang menjadi spesifikasinya dan profesinya. Kondisi mental anak-anak tergantung dari kecintaan guru terhadap mereka dan profesinya, semakin besar kecintaan itu maka semakin baik kondisi mental dan emosional murid. Para guru juga harus menggunakan strategi dan metode mengajar yang bervariasi agar anak-anak murid merasa senang dan tidak stres ketika proses belajar- mengajar. Keteladanan yang baik juga harus diberikan guru kepada murid, karena pendidikan yang efektif ialah dengan teladan dibanding dengan kata- kata.

$$
* * *
$$




\section{DAFTAR PUSTAKA}

A.Suseno Tutu April, EQ Orang Tua VS EQ Anak. Yogyakarta:Diglossia Printika,2009.

Agustian, Ary Ginanjar, ESQ Berdasarkan 6 Rukun Iman dan 5 Rukun Islam. Jakarta: Arga,2002

Ahmad Karzun, Anas, Anak Adalah Amanat. Jakarta: Qisthi Press, 2006

Amini, Ibrahim, Agar Tak Salah Mendidik. Al-Huda : Jakarta,2006.

Amini, Ibrahim, Kiat Memilih Jodoh Menurut Al-Quran dan Sunnah. Jakarta : Lentera, 1996.

Bisri, H.A. Fulex, Ketika Orang Tua Tak Lagi Dihormati, Mujahid Grafis: Bandung, 2004.

Daradjat, Zakiah, Ilmu Jiwa Agama. Jakarta: PT Bulan Bintang,2003.

Departemen Pendidikan dan Kebudayaan. Kamus Besar Bahasa Indonesia. Jakarta: PT.Bina Pustaka,1988.

E.Shapiro, Lawrence, Mengajarkan Emotional Intelligence Pada Anak. Jakarta: PT Gramedia Pustaka Utama, 1999.

Goleman, Daniel Alih Bahasa: Alex Tri Kantjoro, Kecerdasan Emosi Untuk Mencapai Puncak Prestasi. Jakarta: Gramedia Pustaka, 2003

Goleman, Daniel, Kecerdasan Emosional. Jakarta: Pt Gramedia Pustaka Utama, 2000

Goleman, Daniel, Working With Emotional Intelligence. New York : Bantam Books, 1999

Hasbullah. Dasar-Dasar Ilmu Pendidikan. PT Raja Grafindo Persada : Jakarta,2006. Indra Soefandi dan Ahmad Pramoedya, Strategi megembangkan Potensi Kecerdasan Anak. Bee Media Indonesia, Jakarta: 2009

Jalaludin Rakhmat dan Mukhtar Gandaatmaja, Keluarga Muslim dalam Masyarakat Modern. Bandung: Remaja Rosda Karya, 1994 


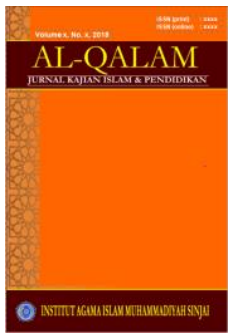

AL-QALAM

Jurnal Kajian Islam \& Pendidikan

Volume 07 No 022015

ISSN (print) : 1858-4152

ISSN (online) : 2715-5684

Homepage : http://journal.iaimsinjai.ac.id/index.php/al-qalam

Lanawati, Sri, Hubungan antara EI dan IQ Dengan Prestasi Belajar, Tesis. Jakarta, Universitas Indonesia,1999

Latifah, Melly "Peranan Keluarga Dalam Pendidikan Karakter Anak", dari www.blogspot.com, 1 Maret 2008

Muhammad Naufal, Abu Ahmad, Langkah Menggapai Kebahagiaan Berumah Tangga. Yogyakarta: Al-Husna Press, 1994.

Nata, Abudin, Filsafat Pendidikan Islam. Jakarta: logos wacana Ilmu, 1997

Poerwanto, M.Ngalim, Ilmu Pendidikan (Teoritis dan Praktis). Bandung : PT.Remaja Rosdakarya, 1995

Puspasari, Amaryllia, Emotional Intelligent Parenting. Jakarta: PT Gramedia, 2009.

Rasyid Dimas, Muhammad, 25 Cara Mempengaruhi Jiwa\&Akal Anak. Pustaka Al-Kautsar : Jakarta,2006

Soelaeman, M.I., Pendidikan dalam Keluarga. Bandung: CV.Alpabeta,1994 Tridhonanto, Al., Melejitkan Kecerdasan Emosi (EQ) Buah Hati. Jakarta: PT Gramedia, 2009 